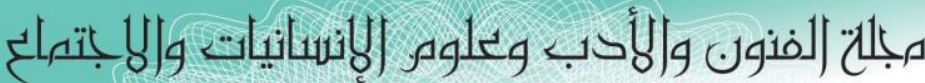

Journal of Arts, Literature, Humanities and Social Sciences

ISSN online: 2414 - 3383

ISSN print: 2616 - 3810

العدد (4O) تهوز - يوليو 2019

\title{
The Effectiveness of Using Correction Techniques on The Achievement of Iraqi Collage learners in Punctuation Marks Accuracy
}

\author{
Asmaa Hussain Jaber \\ Department of English \\ Imam Al-Kadhum University College \\ Baghdad - Iraq \\ E-mail: asmaa.2019@alkadum-col.edu.iq
}

\begin{abstract}
Similar to any additional learning condition, In essence, a second language student must first receive feedback on even their own achievement, so therefore, This work explores the general influence of instructor-correction, peer-correction and personalcorrection techniques of Iraqi college students ' punctuation mark efficiency. The Teacher- correction group obtained correction and tacit coding responses from the instructor and the peer-correction group-obtained correction and tacit coding responses from their colleagues; whereas these group members themselves corrected and edited their work in the self-correction group. The study samples second-year participants studied at the College of Imam Al-Kadhum, Department of English mainly consisting of two hundred (200) second-year students in the academic year of 2018/2019. This experiment was attended by a group of (120) learners, comprising of four classes of thirty-three (33). At the start of the term, all the participants took pretests and then engaged in a 6-week activity in which they had distinct feedback techniques. The post-test one-way ANOVA findings showed a substantial distinction between the accomplishment of the three groups. The Scheffe Test results showed a significant difference between instructor-correction and personal-correction groups and between instructor-correction and peer-correction groups. The verdict of this assessment is that groups of peer-correction and self-correction show better teaching
\end{abstract}




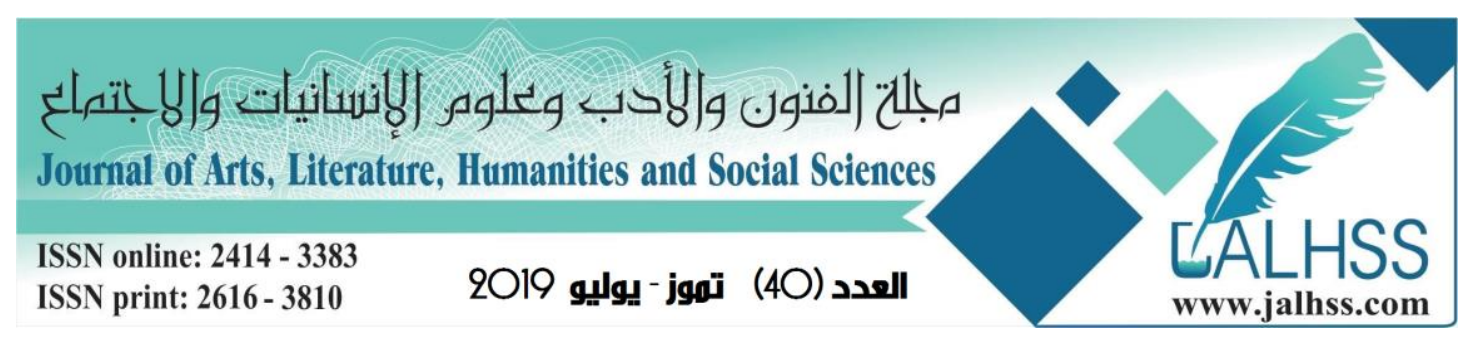

performance relative to the conventional group of teacher-correction, and peercorrection serves as the best feedback method.

\section{Introduction}

Considering the multitude of functions performed by a language teacher, providing learner feedback is the most prominent. Changing the methods away from classical methods to Communicative Language Teaching has altered the teacher's mandate to provide feedback. Traditionally the language teacher was supposed to be the only reference; it was his or her sole prerogative to present ideas and provide correction. However, recent approaches and methods place a greater emphasis on learners' cognition and induce autonomy (Sultana, 2009: 11).

With that shift, developments such as, student-oriented error correction techniques They have come to the fore, including peer correction or self-correction. This paper evaluates three kinds of feedback on correction: personal-correction, peer-correction and instructor -correction and tries to ascertain the suitability of applying these classroom techniques to academic disciplines in Iraq. Also, the researcher attempts to illustrate the fundamental importance of various types of punctuation marks, to develop learner achievement with voice accentuation, intonation and physical expression in written works, with a view to finding the best methods and techniques to teach them punctuation. They convey value and express associations among concepts;, therefore it is essential to select correct punctuation marks to enhance expression and define the relationships with learners' ideas.

The investigator is interested in understanding the connection between the punctuation mark errors made by students in a variety of compositions and the implemented teacher's response to such errors using three types of feedback.

Unsatisfactory student achievement instigated the lecturers to look for information about effective techniques to correct standard errors made by many students. In this study, that happened with the emergence of the process writing approach in second language pedagogy, correction (giving feedback). Considering the process is an essential tool for improving and developing, Three kinds of correction are available (self, peer and teacher). So the purpose of this work is therefore to determine the possible impacts of instructor-correction, peer-correction and personal-correction techniques on the precision of the punctuation mark of the learners. The current research is an effort to investigate the impacts of instructor, peer, and personalcorrection in the form of focused training on decreasing mistakes in the use of the: apostrophe; colon; dash; comma; ellipsis; exclamation mark; hyphen; parentheses; period; question mark; quotation mark; and semicolon.

Correction here relates to educators, colleagues, and learners themselves correcting mistakes. The study focuses on the most familiar marks by discussing the implicit feedback and its impact on punctuation precision in the performance of learners in any writing. Consequently, the study's importance is multifaceted. First, it emphasizes that a correction is a suitable instrument for student improvement, Secondly, this 


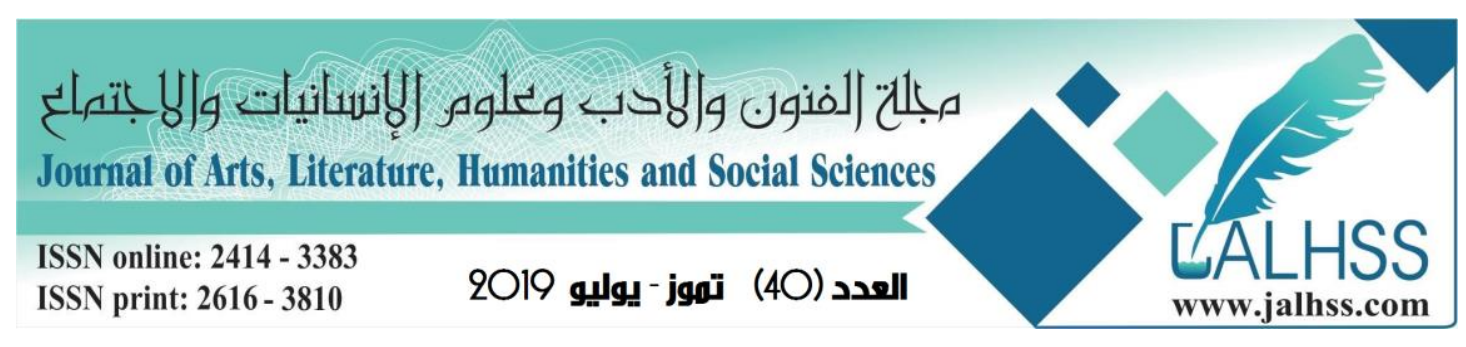

research highlights the significance of form-focused training in the performance of learners to improve punctuation precision.

Finally to address personal-correction, the application of an optimal combination of form-focused and instructor instruction reduces errors with punctuation marks.

\subsection{The Problem of the Study and Its Significance}

According to the researcher's observation to student's achievement and through her teaching writing materials to second stage students at the English department at the college of Imam Al Khdhun (A.S), the researcher states that being able to write a foreign text with a degree of accuracy using punctuation marks is difficult for Iraqi learners.

This research attempts to highlight the significance of various types of punctuation marks. This development aims to help learners compensate for reduced voice intonation and physical expression in their writing. Punctuation conveys intent and makes associations between ideas; thus, it is essential to select the punctuation mark that best expresses the relationship intended by the learner.

The researcher presumes that Iraqi English students create many written errors regarding punctuation - this phenomenon is notable in almost every course run by the researcher.

Consider these two sentences:

Eat children

Eat, children.

Both sentences issue a command; however, the first sentence would only apply to cannibalistic societies who eat human flesh. Oshim and Hogue (1991). Incorrect punctuation is indicative of unclear texts. (Ming, 2006; Rumki, 2005 and Connelly, 2005).

Simultaneously, the writer must take care of the punctuation marks when composing any writing. In general, there are fourteen marks. The researcher uses only the most familiar ones: apostrophe; colon; dash; comma; ellipsis; exclamation mark; hyphen; parentheses; period; question mark; quotation mark; and semicolon. So, the problematic use of using punctuation marks led the researcher to think of a new teaching technique to improve student ability in mastering punctuation marks. The researcher thinks about peer-correction, self- correction and teacher-correction techniques, which are designed to help the students, become better in overcoming the errors made when they used such marks.

Therefore, the situation is problematic and requires some remedy for the sake of improvement and development, i.e., since methods and techniques in teaching English may have an effect on the failure of improving students' skills, teachers and educators have to develop and adopt $t$ avariety of learning methods and techniques that may help students to become good writers. 


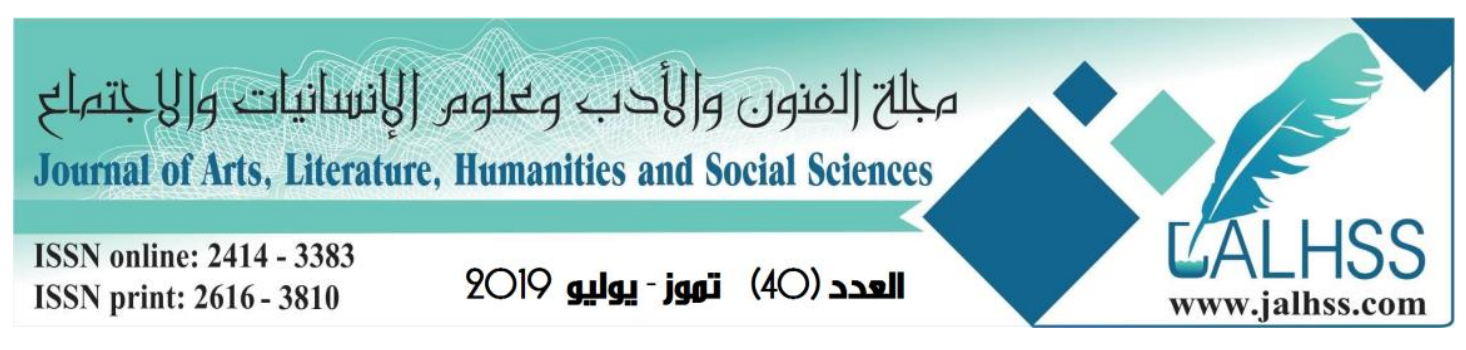

\subsection{Aims}

This research seeks to find out the efficacy of using correction techniques of instructor-correction, peer-correction, and personal-correction to master the right implementation of punctuation marks by Iraqi EFL college learners.

\subsection{Hypotheses}

For the purposes of this study, the following two null hypotheses are developed: (1) no statistically important difference in the post-test between the means of accomplishment of the outcomes of the experimental group scores (instructor correction group, group of personal-correction and group of peer-correction and group of control). (2) There is no statistically significant distinction between means of accomplishment

\subsection{Procedures}

These procedures are as follows in order to fulfill the objectives of the current research and to verify the hypotheses:

(a). Selecting a representative sample from the population of the study and dividing it into three groups.

(b). Describing the presentation of materials for the experimental groups and the control group.

(c). Constructing and validating the pre-test and the post-test to be used as tools of investigation.

(d). Experimenting with applying the suggested approaches: process writing approaches; and free-writing approaches.

(e). Using the appropriate means to analyse the test results.

(f). Putting forward pedagogical recommendations and suggesting some projects based on the findings of the present study.

\section{1-5 Limitation of the study}

This work is restricted to second-year learners in the English Department at the College of Imam Al-Kadhim(A.S). For the second half of the academic year 20182019.

\section{1-6 Value of the Study}

1. The present study expects to be of value to help Iraqi college students overcome their difficulties using punctuation marks.

2. It also expects to help instructors develop appropriate methodologies to teach punctuation marks considering the use of personal-correction, peer-correction and instructor-correction.

\section{Theoretical Framework}

\subsection{Correction Techniques}

For any ELT class, correction is essential as learners consider correction as a source o f enhancement. (Chaudron, 1988, as cited in Celce-Murcia, 2001). Errors are seldom considered to result from 'not learning'; conversely . Considered as the result of procedures of natural language. In this sense the teacher seldom correct errors; he or she facilitates learning to engage the students themselves in the methodology of 


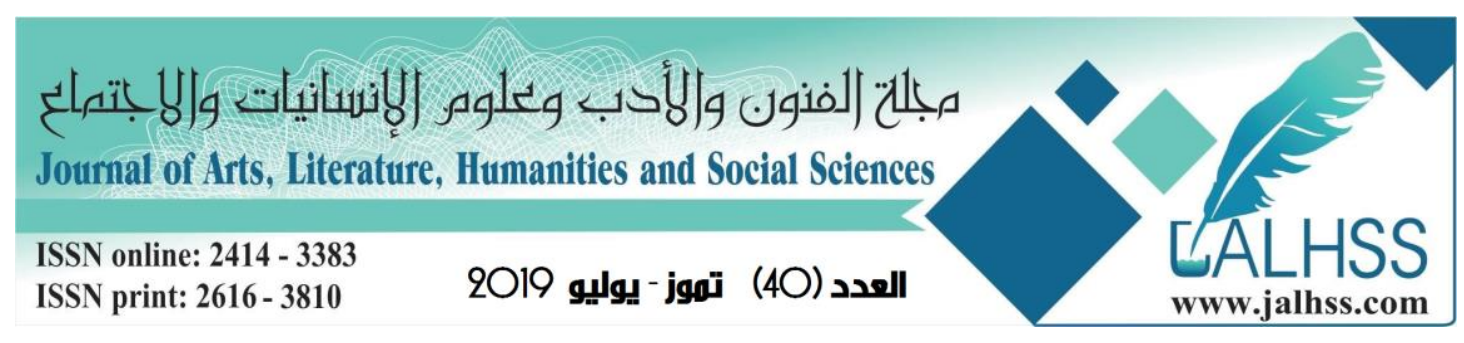

correcting errors. However, the teacher should determine the appropriate time for correction, the best method for correction and decide whether the correction process is necessary.

Several kinds of correction are available (Brown, 2007; Celce-Murcia, 2001): Explicit or Direct (Brown, 2007), Implicit or Indirect (Richards \& Schmidt, 2002), Peer-correction (Paulston \& Bruder, 1976), Self-correction (Swain, 1985), Repeat, Recast, Metalinguistic feedback, Elicitation (Brown, 2007). According to Brown (2007, p. 379), correction guidance involves answers to learners., which amend or recognise their errors. ELT classrooms mistakes might happen from correction by the teacher, the learner or others.

The apparent technique perceived by most is correction of teachers. In a typical classroom environment, The teacher and the learners presume that the teacher should remedy the mistakes of all the learners. Since classical thought on the matter asserts that the teacher imparts knowledge to the students, that thinking is logical since he or she will grade student achievement. When correction comes from the teacher, it strengthens the power of the teacher. In a traditional environment of the language class, , the teacher commands authority, maintains discipline and he or She is regarded as the sole source of information. Students play a passive role to receive information. However, this dominating teaching environment becomes less pervasive through the practice of peer or self-feedback. (ibid:54 )

Self-correction as described by Sultana (2009: 11) is: "a method that involves learners in correcting their mistakes." In other words, self-correction occurs when the speaker perceives mispronunciation, unsuitable grammar, or a bad selection of phrases and corrects them quickly (Lam, 2006: 144).

A concept strongly connected with self-correction is learner autonomy, i.e. they become autonomous when facilitators promote learners to correct their own errors. As Makino (1993: 340) puts it:" when they have the chance to consider and activate their language skills, they become active participants." Consequently, as many academics have suggested (e.g. Makino, 1993, Rief, 1990), correction of teachers may be useful to some learners. But self-correction may be more beneficial and needs to be encouraged.

In contemporary learner-centered instructional environments practicing cooperative learning and emphasizing learner autonomy, self-correction is required and has proved to be crucial up to now (Edwards, 2000; Rief, 1990; Sultana, 2009). However, as also suggested by Sultana (2009), the specific context of education and learners requires thorough examination before any method or technique is adopted.

The peer-correction technique is an interactive process of reading and commenting on classmate's work, or reading each other's work to make helpful comments to improve one's classmate's content and organisation (Oshima and Ann 1999:29)

Gaudini in Hadley (2002:331) defines peer editing in the class editing context as students helping one another improve their writing through a series of passes. Peer correction in class happens when students' make proposals or assertions and the 


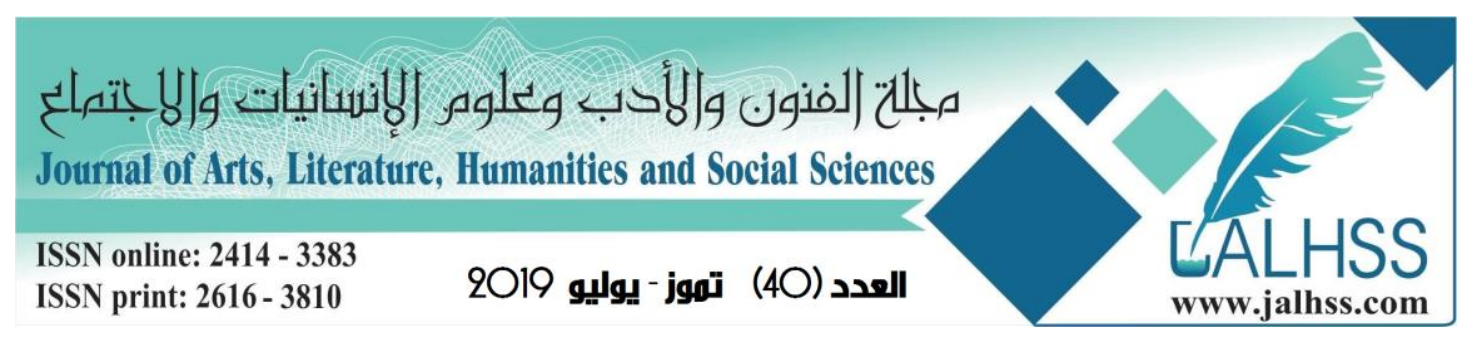

question asked to the class is: "Do you think that is right?". Alternatively, suggest they add a constructive written comment on another pupil's completed writing (Jeremy Harmer, 2007). Peer correction enhances learner autonomy in the classroom, improves cooperation, facilitates interaction and proactively increases participation in the classroom. Most language educators use this method in schools and sometimes do not know about these theories.

Another significant classroom teaching issue manifests with peer correction. Most practitioners acknowledge that student participation enhancement in the classroom aids better learning, and involvement surely improves that when students give positive comments regarding their peer's performances (Gower et al. 1995).

\subsection{Punctuation Marks}

For simplicity and to explain the work organisation, this section highlights the other research activities, to clarify where research converges and where it differs. The section looks at the intricacy levels of punctuation from each study and provides suggestions to remedy any errors. Regarding effectual or ineffectual punctuation, some studies demonstrate the crucial nature of this dilemma. Meyer (1985:43), for instance, finds that teachers present punctuation precision as the distinguishing factor in determining "good" and "bad" writing. Furthermore, a straightforward writing style, requires learners to properly select the suitable punctuation marks in an easy to read format, that selection enables the reader to appropriately and meaningfully understand the intended message.

Rumki (2005:76) asserts that incorrect punctuation might hinder the progress of ideas and significance shift in meaning, but properly used punctuation also enables the reader to comprehend one's purpose and embrace it in the text. Additionally, Robinson (2002:32) states that correct punctuation facilitates clear thought. The overuse of punctuation is a professional hazard to most teachers; although the rules are essential, by themselves, they are insufficient. Unless one fixates upon them, rules are often quickly misremembered. Learners and teachers must focus their attitude toward punctuation, emotionally about the general process and the individual punctuation marks. The definition of that emotion might be called a philosophy of punctuation. He further asserts that punctuation conveys two ideas: clarity and plainness. The primary role of punctuation is to contribute to the simplicity of one's meaning - the secondary role being inconspicuous, drawing little attention away from the written content.

Al-Mutib (1989) focuses on the use of the semicolon, which is applied to connect two related clauses, and explains its infrequent use. Too often the comma is inappropriately applied to link two clauses, which often results in a run-on sentence. Punctuation also influences the emphasis the reader places on the word or phrase. For instance, a period's emphatic reaction is distinct from an exclamation mark. There is more force in a colon or dash than a comma. For instance: 


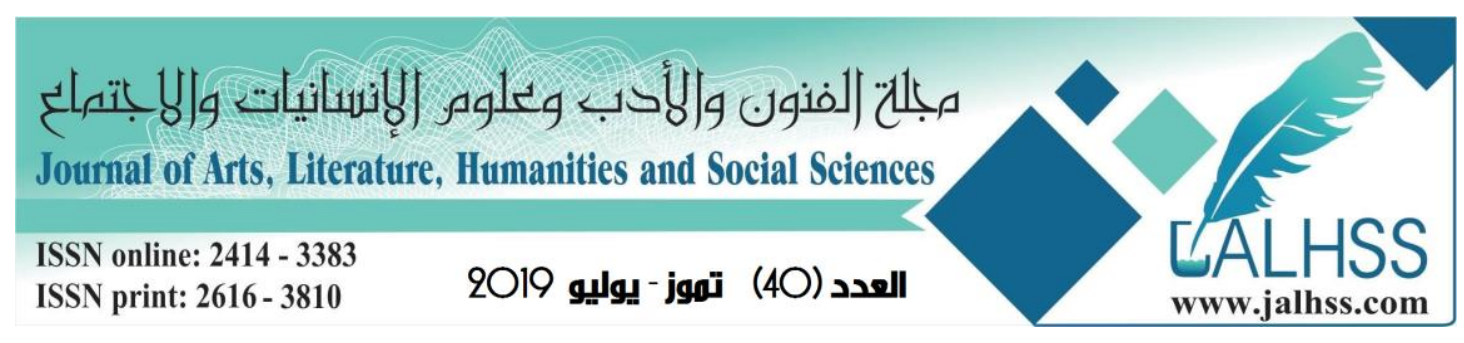

The staff were surprised by the decision of the head office, which was not to alter the policy of the business.

The staff were surprised by the judgment of the head office - no change in corporate policy.

The staff were surprised by the judgement of the head office: no change in business policy.

Both Al-Mutib (1989: 34) and Khalil (2000) remark that Palestinian EFL students frequently make written errors with commas and periods ; most prevalent error types pertained to comma splices and superfluous commas. An inappropriate comma is an unnecessary comma and happens when comma insertion happens in the wrong place to over punctuate sentences.

This current study supports the assertion of Gaines (2002), who presupposes that the arrangement of the most common errors that learners of English demonstrate happens with the frequency of error. These errors happen within the following order incorrect application of a comma to replace the semi-colon or vice versa. The most frequently used punctuation is probably the comma, so frequently comma errors appear in student writing. Often students perceive that commas insertion happens whenever a pause is required. That assumption is incorrect and probably the cornerstone to most comma errors. Gaines (2002) explains the use of conjunctive adverbs such as "however", "therefore", and "moreover", a semicolon should apply when they connect two independent clauses; also true for transitional phrases such as "in fact" or "besides".

Daniel (2004) explains another area where learners fail to perceive the associated pause correctly. Pausing differs between punctuation marks to change the meaning - for example:

"Do you realise what happens?"

"Do you realise what happens!"

The first example is a question, denoted by the question mark and it requests an answer and a pause for a reply. In the second example, the exclamation mark implies a statement rather than a question. The exclamation mark provides emotional emphasis on that statement. The use of the exclamation mark in the second sentence implies rhetoric and requires no answer and hence less pause.

So, the situation is problematic and needs some attention for the sake of development and improvement, the researcher here suggests the following pedagogical techniques in teaching punctuation marks which are teacher-correction, self-correction and peer-correction techniques.

\section{Research Methodology}

Research is categorized into experimental kinds of research because the investigator is doing the subjects a therapy. It used an in equivalent design of control group because the investigator did not randomly select the research subjects. This study examined the effectiveness of using peer, self and teacher correction techniques on students' performance in the accuracy of punctuation marks. The experiment was done for two months from November 2018 to January 2019. The sample of this work 


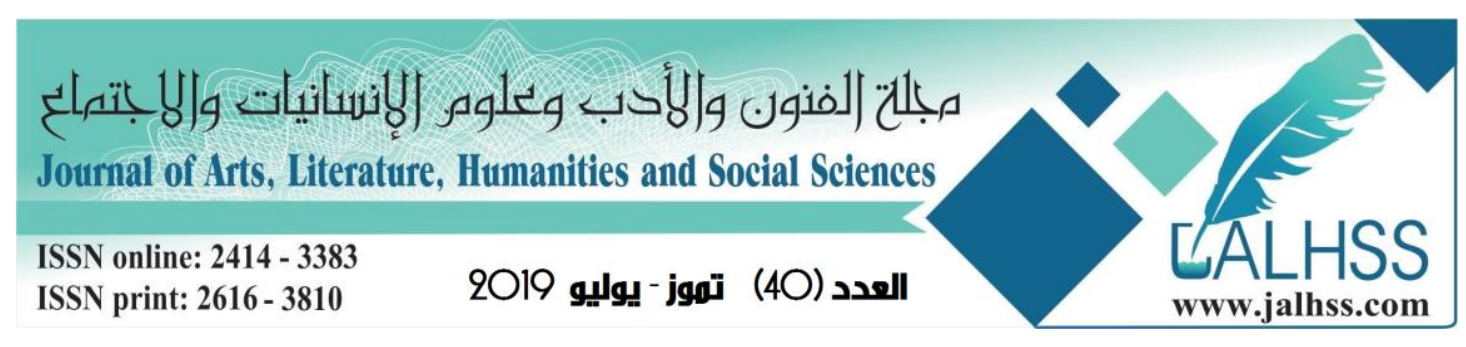

were the second stage students Department of English in Imam Al-Kadum University College consisting of four classes (morning and evening studies).With 200 learners in total. The investigator used purposeful sampling to take 120 learners as a sample in this research - classes with 32 learners each. The investigator used a pre-test and post-test writing test as the tool for collecting the information. The information collection steps were the preparation of the tool, pre-testing, therapy, post-testing, and information evaluation. The investigator used descriptive and inferential statistics to analyse the information. See Table (1):

\begin{tabular}{|c|c|c|c|}
\hline Group & Test & Treatment & Post test \\
\hline Experimental 1 & Pre-test & Peer-editing & Post-test \\
\hline Experimental 2 & Pre-test & Self-editing & Post-test \\
\hline Experimental 3 & Pre-test & $\begin{array}{c}\text { Teacher- } \\
\text { editing }\end{array}$ & Post-test \\
\hline Control & Pre-test & --------------- & \\
\hline
\end{tabular}

Table (1) The Experimental Design (abbot and mckinny,2013: 76)

\section{1 Population and Sample Administration}

\subsubsection{Population}

Richard and et al. (1992: 282) assert that population denotes any set of items, individuals, etc. that are observably similar in terms of their sampling characteristics. The population of the present study covers the second-year college students of English Department in Imam AL-Khadum College in Baghdad for the first half of the academic year 2018-2019.

\subsubsection{Sample}

A sample of students from four classes studying English, attending the college of Imam Alkhadum in Baghdad took part in this study. The complete number of students is (120), who were divided into four groups or sections: Section A comprises of (33) students who were chosen to be the first experimental group (peer- correction), and Section B consists of (33) students who were selected to be in the second experimental group (self-correction). Section C comprises of (33) students assigned to be the third experimental group (teacher-correction). Section D selected to be the control group (they received traditional ways of feedback). For this study, the classes are integrated into the four groups by randomly drawing lots, considering the complete number of students.

\subsection{Instruments of the Study}

To validate the original pre-test and post-test requires input from Linguistics and ELT experts. These experts provided a view on all the items and judged all but one of the items to be valid; therefore that invalid viewpoint was replaced. The final form of the test consists of 2 items. 


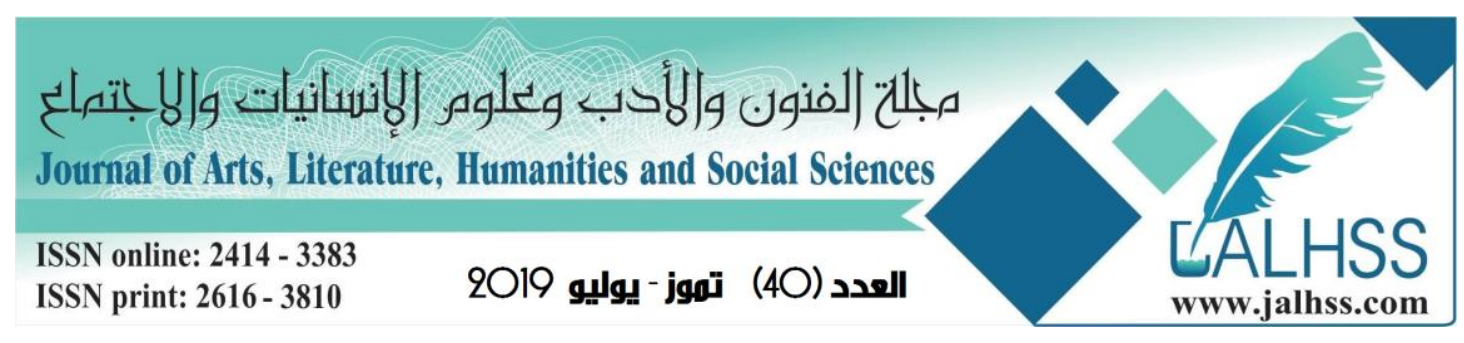

To ensure test instruction clarity requires an estimation of the time required by the students to decipher the test items. The test is not severely ambiguous, and the pilot sample of the study happened on the 17th of Feb 2019 with 33 second-year students, section "A" at the English Department, College of Imam Al-Khudum. The ascertained test duration is 50 minutes. The test reliability is derived using The Pearson Correlation Coefficient Formula, which obtains a correlation of the Coefficient of the odd-numbered students' scores against the even-numbered test item scores - the derived reliability Coefficient is (0.92).

\subsection{The Experiment Application:}

The experiment commenced on the 17th of February 2019, lasting six weeks during the second half of the academic year (2018-2019) so concluded on the 25th of March of the same year. The arrangement of lectures for the control group and the experimental groups happened on Sunday.

\subsubsection{The Control Group:}

The researcher herself taught the control group using a conventional way to teach writing for two hours per week. The prescribed textbook, 'The Introduction to Academic Writing' provided the entire basis for the material used to teach writing to the control group. Typically, the instructor explains and states the uses of some punctuation marks found in their textbooks and then ask the student to do exercises.

\subsubsection{The Experimental Groups:}

Recording of results happened after the pre-test; the treatment lasted for six weeks. In each lecture and to all groups (experimental and control) the instructor did not just teach a plethora of boring punctuation rules. However, she gave the students practical experience by putting them in the proof-reader's seat with these grades one to eight punctuation unit specialising in quotation marks, apostrophes, commas, semicolon etc. in every possible category. Students can exercise their knowledge and move from the basics to more complex situations by correcting errors in sentences or an entire lowercase essay.

In addition to that, the instructor uses a wide array of activities that help students aim for punctuation perfection. In each lecture, the instructor explains one or two marks then at least states the uses of them and how to avoid some written errors when used. Moreover, the instructor asked the student to do the exercises. A presentation to inform the students about this teaching and error correcting activity ensued. The classes were taught all of the essential points of punctuation marks, after that, the students were assigned to write a paragraph consisting of 50 to 80 words as weekly homework and bring it to the class for correction. In the self-correction group, students were required to read and rewrite their papers themselves; The peercorrection group required students to review and rewrite their papers with their classmates; Students attending the teacher-correction group, had to review and rewrite their papers considering the teacher's feedback. The teacher provided feedback, and made all the necessary revisions to the original work, in the teacher- 


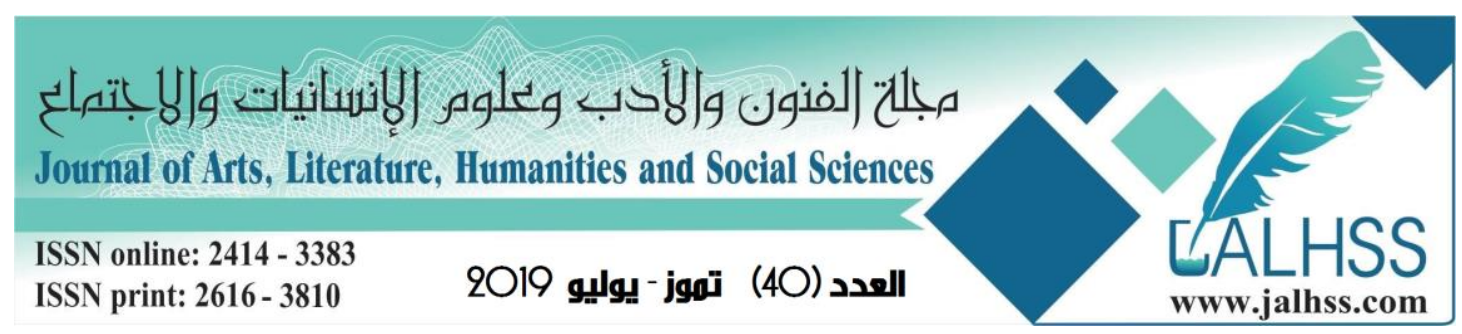

correction group; the students subsequently rewrote their works with remarks. In the self-correction group B, The teacher reviewed the work and provided corrective feedback to the students; the students corrected their paper themselves and rewrote them again. In the Peer-correction group C, the students worked to review another peer's work and in groups of three rewrote their papers.

\section{Findings and Discussion}

\subsection{Student's Performance of the EG 1(Peer-correction group) on The Pre-test and Post-test}

The mean score of the first experimental group, which is taught by the peercorrection technique on the pre-test is found to be $(4,00)$; whereas in the post-test it is $(6,75)$. The t-test formula for paired samples has been used to show if there is any significant difference between the means of the EG on the pre-test and post-test. The calculated $t$-value is $(-6,566)$, whereas the tabulated $t$-value is $(2,042)$ of significance at $(0,05)$ and $(31)$ degrees of freedom, this shows that there is a statistically important distinction in favor of post-test results between pre-test and post-test.

\begin{tabular}{|c|c|c|c|c|c|c|c|c|}
\hline \multirow[b]{2}{*}{ Group } & \multirow[b]{2}{*}{ Test } & \multirow[b]{2}{*}{$\mathbf{N}$} & \multirow[b]{2}{*}{ Means } & \multirow[b]{2}{*}{ SD } & \multirow[b]{2}{*}{ DF } & \multicolumn{2}{|c|}{ T value } & \multirow[b]{2}{*}{ Significance } \\
\hline & & & & & & Calculate & Tabulate & \\
\hline \multirow[t]{2}{*}{ EG1 } & $\begin{array}{l}\text { Pre- } \\
\text { test }\end{array}$ & \multirow[t]{2}{*}{32} & 4,00 & 2,170 & \multirow{2}{*}{31} & \multirow[t]{2}{*}{$-6,566$} & \multirow{2}{*}{2,042} & \multirow{2}{*}{$\begin{array}{c}\text { Significance } \\
\text { for the post } \\
\text { test }\end{array}$} \\
\hline & $\begin{array}{c}\text { Post } \\
\text { test }\end{array}$ & & 6,75 & 1,723 & & & & \\
\hline
\end{tabular}

Table (2) the overall performance of the EG1 on the pre-test and post-test

\subsection{Student's Performance of The EG 2 (Self -correction group) on The Pre-test and Post-test}

The mean score of the second experimental group, which is taught by a self-correction technique on the pre-test is found to be $(3,34)$; whereas in the post-test it is $(5,81)$. The t-test formula for paired samples has been used to show if there is any significant difference between the means of the EG2 on the pre-post-test. The calculated t-value is $(5,291)$, whereas the t-value was $(2,042)$ at $(0,05)$ level level of significance and (31)degrees of freedom . These concentrations show a statistically significant distinction in favor of the post-test results between the pre-test and post-test. 


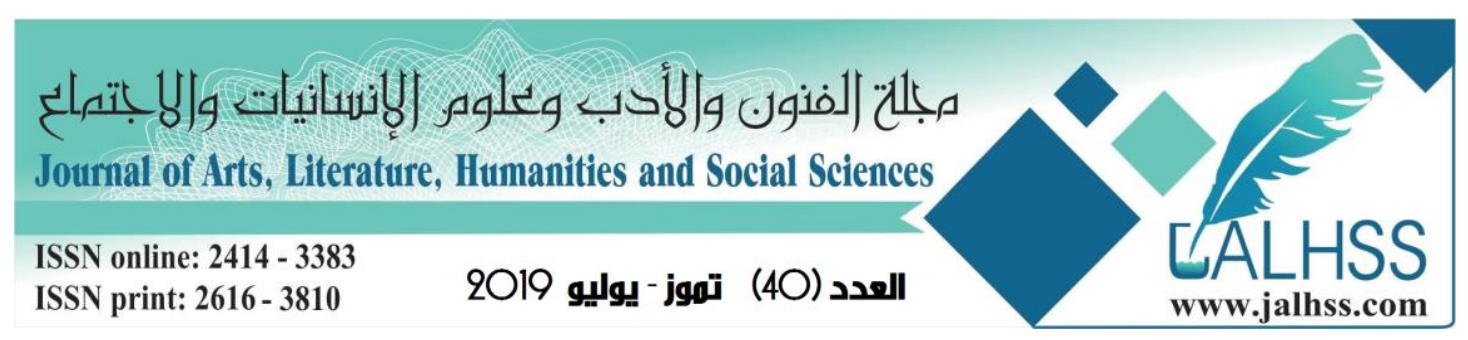

\begin{tabular}{|c|c|c|c|c|c|c|c|c|}
\hline \multirow[b]{2}{*}{ Group } & \multirow[b]{2}{*}{ Test } & \multirow[b]{2}{*}{$\mathbf{N}$} & \multirow[b]{2}{*}{ Means } & \multirow[b]{2}{*}{ SD } & \multirow[b]{2}{*}{ DF } & \multicolumn{2}{|c|}{$\mathbf{T}$ value } & \multirow[b]{2}{*}{ Significance } \\
\hline & & & & & & Calculate & Tabulate & \\
\hline \multirow{2}{*}{ EG2 } & $\begin{array}{l}\text { Pre- } \\
\text { test }\end{array}$ & \multirow{2}{*}{32} & 3,34 & 2,458 & \multirow{2}{*}{31} & \multirow{2}{*}{5,291} & \multirow{2}{*}{2,042} & \multirow{2}{*}{$\begin{array}{c}\text { Significance } \\
\text { for the post } \\
\text { test }\end{array}$} \\
\hline & $\begin{array}{c}\text { Post } \\
\text { test }\end{array}$ & & 5,81 & 1,674 & & & & \\
\hline
\end{tabular}

Table (3) the overall performance of the EG2 on the pre-test and post-test

\subsection{Student's Performance of The EG3 (Teacher - correction group) on The Pre- test and Post-test}

The mean score of the third experimental group, which is taught by a teacher correction technique on the pre-test is found to be $(3,31)$; whereas in the post-test it is $(6,09)$. The t-test formula for paired samples has been used to show if there is any significant difference between the means of the EG3 on the pre-test and post-test. The calculated t-value is $(9,588)$, whereas the $t$-value is $(2,042)$ at $(0,05)$ level of significance, and (31) degrees of freedom . These concentrations show a statistically significance distinction in favor of the post-test results between the pre-test and the post-test.

\begin{tabular}{|c|c|c|c|c|c|c|c|c|}
\hline \multirow[t]{2}{*}{ Group } & \multirow[t]{2}{*}{ Test } & \multirow[t]{2}{*}{$\mathbf{N}$} & \multirow[t]{2}{*}{ Means } & \multirow[t]{2}{*}{ SD } & \multirow[t]{2}{*}{ DF } & \multicolumn{2}{|c|}{ T value } & \multirow[t]{2}{*}{ Significance } \\
\hline & & & & & & Calculate & Tabulate & \\
\hline \multirow[t]{2}{*}{ EG 3} & $\begin{array}{l}\text { Pre- } \\
\text { test }\end{array}$ & \multirow[t]{2}{*}{32} & 3,31 & 2,206 & \multirow[t]{2}{*}{31} & \multirow[t]{2}{*}{9,588} & \multirow[t]{2}{*}{2,024} & \multirow[t]{2}{*}{$\begin{array}{l}\text { Significance } \\
\text { for the post test }\end{array}$} \\
\hline & $\begin{array}{l}\text { Post } \\
\text { test }\end{array}$ & & 6,09 & 1,594 & & & & \\
\hline
\end{tabular}

Table (4) The Overall Performance of The EG3 on The Pre-test and

Post-test

\subsection{Student's Performance of The Control Group on The Pre-test and Post-test.}

It is discovered that the mean score of the control group is learned using traditional teacher methods in pre-test correction to be $(3,91)$; whereas in the post-test it is (4.34). The t-test formula for paired samples is used to show if there is any significant difference between the means of the CGon the pre-test and post-test. The calculated $\mathrm{t}$ value is $(0,739)$ whereas the table $t$-value is $(2,042)$ at $(0,05)$ level of significance, and (31) degrees of freedom, indicating a statistically significant distinction between pre-test and post-test results in favour of the post-test performance. 


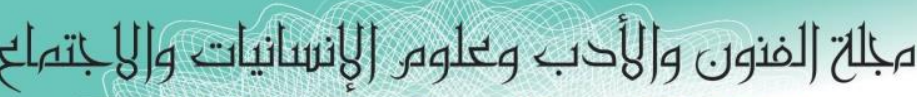

Journal of Arts, Literature, Humanities and Social Sciences

ISSN online: 2414 - 3383

ISSN print: 2616 - 3810

العدد (40) تموز - يوليو 2019

\begin{tabular}{|c|c|c|c|c|c|c|c|c|}
\hline \multirow{2}{*}{ Group } & \multirow{2}{*}{ Test } & \multirow{2}{*}{$\mathbf{N}$} & \multirow{2}{*}{ Means } & \multirow{2}{*}{ SD } & \multirow{2}{*}{ DF } & \multicolumn{2}{|c|}{ T value } & \multirow{2}{*}{ Significance } \\
\hline & & & & & & Calculate & Tabulate & \\
\hline \multirow{2}{*}{$\mathrm{CG}$} & $\begin{array}{c}\text { Pre- } \\
\text { test }\end{array}$ & \multirow{2}{*}{32} & 3.91 & 2.263 & \multirow{2}{*}{31} & \multirow{2}{*}{0.739} & \multirow{2}{*}{2.042} & \multirow{2}{*}{ Not Significant } \\
\hline & $\begin{array}{c}\text { Post } \\
\text { test }\end{array}$ & & 4.34 & 2.789 & & & & \\
\hline
\end{tabular}

Table (5) The Overall Performance of The CG on The Pre-test and Post-test

\subsection{Results of Hypothesis 1}

This study uses the ANOVA formula to verify hypothesis 1 . The means of the scores of the performance of three groups are compared using a one-way analysis of variance (ANOVA), as shown in the table (6).

\begin{tabular}{|c|c|c|c|c|c|}
\hline Group & $\mathrm{N}$ & & Means & \multicolumn{2}{|c|}{ standard deviation } \\
\hline EG1 & \multicolumn{2}{|l|}{32} & 6.75 & \multicolumn{2}{|l|}{1.723} \\
\hline EG2 & \multicolumn{2}{|l|}{32} & 5.81 & \multicolumn{2}{|l|}{1.674} \\
\hline EG3 & \multicolumn{2}{|l|}{32} & 6.09 & \multicolumn{2}{|l|}{1.594} \\
\hline CG & \multicolumn{2}{|l|}{32} & 4.34 & \multicolumn{2}{|l|}{2.789} \\
\hline Total & \multicolumn{2}{|c|}{\begin{tabular}{|l|l}
128 \\
\end{tabular}} & 5.75 & \multicolumn{2}{|l|}{2.170} \\
\hline \multicolumn{6}{|c|}{ TABLE (6) ONE-WAY ANALYSIS OF VARIANCE (ANOVA) } \\
\hline $\begin{array}{c}\text { Source of } \\
\text { variation }\end{array}$ & $\begin{array}{l}\text { Sum of } \\
\text { squares }\end{array}$ & $\mathrm{DF}$ & Mean square & Calculate F & Tabulated \\
\hline Between Groups & 99.188 & 3 & 33.063 & \multirow{3}{*}{8.219} & \multirow{3}{*}{2.60} \\
\hline Within Groups & 498.813 & 124 & 4.023 & & \\
\hline Total & 598.000 & 127 & & & \\
\hline
\end{tabular}

TABLE (7) RESULTS OF THE ANOVA OF THE ACHIEVEMENTS OF THE FOUR GROUPS

From the above table it is evident that the calculated $(\mathrm{F})$ value is (8.219) greater than the tabulated $(\mathrm{F})$ value (2.60) at (0.05) level of significance and (.3.124) degrees of freedom, which implies that there is a statistically significant distinction between the three groups in their accomplishment in favor of the EGs. Thus, the first aim of the study is achieved with the rejection of hypothesis 1 . The alternative hypothesis should read: there is a statistically significant difference between the means of the achievement scores in experimental groups (teacher-correction group, peer correction group and self-correction group) and that of the control group.

\subsection{Results of Hypothesis 2}

Hypothesis 2 concerns the comparison between the performance of the experimental 


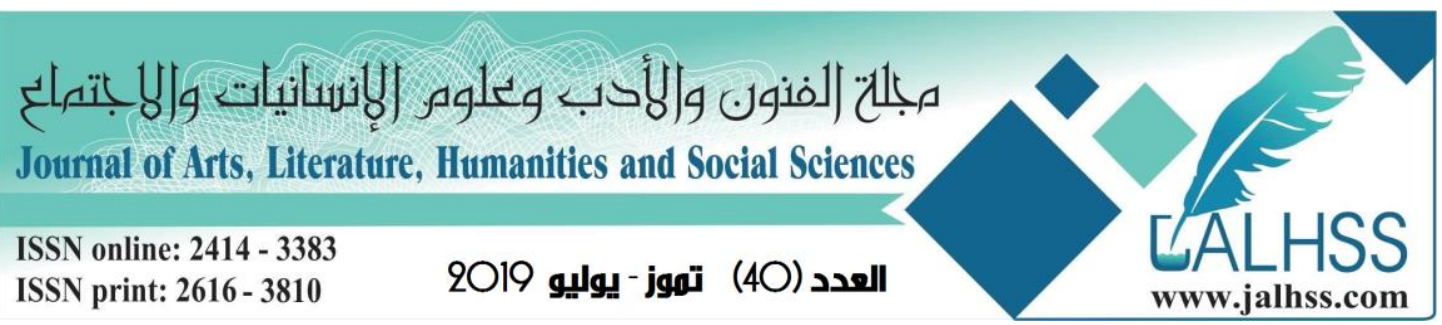

group's teacher - correction, self- correction and peer- correction techniques to identify which technique has more effect than the other on teaching punctuation marks. The Sheveyh test formula shows the direction of difference and indicates the favour for each group.

The results have shown that the performance of peer-correction group on the post-test has been higher than of the teacher - correction group and self- correction group, which indicates that using peer- correction technique is more effective than using self and teacher-correction techniques to teach punctuation marks to second stage students. Table (8) presents these details

TABLE (8) SHEVEYH TEST

\begin{tabular}{|c|c|c|c|c|c|c|}
\hline & Group & $\mathbf{N}$ & Mean & $\begin{array}{c}\text { Difference } \\
\text { between } \\
\text { means }\end{array}$ & $\begin{array}{c}\text { Sheveyh } \\
\text { value }\end{array}$ & Significance \\
\hline \multirow{2}{*}{1} & EG 1 & 32 & 6.75 & \multirow{2}{*}{0.94} & \multirow{2}{*}{1.400} & \multirow{2}{*}{ Non-Significant } \\
\hline & EG2 & 32 & 5.81 & & & \\
\hline \multirow{2}{*}{2} & EG 1 & 32 & 6.75 & \multirow{2}{*}{0.66} & \multirow{2}{*}{1.400} & \multirow{2}{*}{ Non-Significant } \\
\hline & EG3 & 32 & 6.09 & & & \\
\hline \multirow{2}{*}{3} & EG 1 & 32 & 6.75 & \multirow{2}{*}{2.41} & \multirow{2}{*}{1.400} & \multirow{2}{*}{$\begin{array}{c}\text { Significant for } \\
\text { EG1 }\end{array}$} \\
\hline & $\mathbf{C G}$ & 32 & 4.34 & & & \\
\hline \multirow{2}{*}{4} & EG2 & 32 & 5.81 & \multirow{2}{*}{0.28} & \multirow{2}{*}{1.400} & \multirow{2}{*}{ Non-Significant } \\
\hline & EG3 & 32 & 6.09 & & & \\
\hline \multirow{2}{*}{5} & EG2 & 32 & 5.81 & \multirow{2}{*}{1.47} & \multirow{2}{*}{1.400} & \multirow{2}{*}{$\begin{array}{l}\text { Significant for } \\
\text { EG2 }\end{array}$} \\
\hline & CG & 32 & 4.34 & & & \\
\hline \multirow{2}{*}{6} & EG3 & 32 & 6.09 & \multirow{2}{*}{1.75} & \multirow{2}{*}{1.400} & \multirow{2}{*}{$\begin{array}{l}\text { Significant for } \\
\text { EG3 }\end{array}$} \\
\hline & CG & 32 & 4.34 & & & \\
\hline
\end{tabular}

\subsection{Conclusion}

The study demonstrated that Peer-correction and personal-correction were much more effective than the traditional instructor -correction method. Peer-correction was shown to be the best method of giving feedback. While the teacher-correction techniques waste time and energy. However, the two methods of personal-correction technique and peer-correction technique were very productive and improved student achievement and precision. The adherence to this recommendation: that teachers employ these two powerful techniques in their courses should improve their class's activity and achievement. Furthermore, peer-correction enhanced the students' ability to acquire new knowledge and explore learning opportunities, focusing their selective attention to the issues surrounding work content and organisation. Through selflanguage discovery, peer-correction empowered students to question ideas, learn new concepts and gain confidence. The peer-correction group themselves explained they mostly focused on meaning not form. That necessitates educators to experiment with a broader range of error-correction and feedback approaches tailored to the variety of student levels. This paper starts an exciting conversation and this topic warrants 


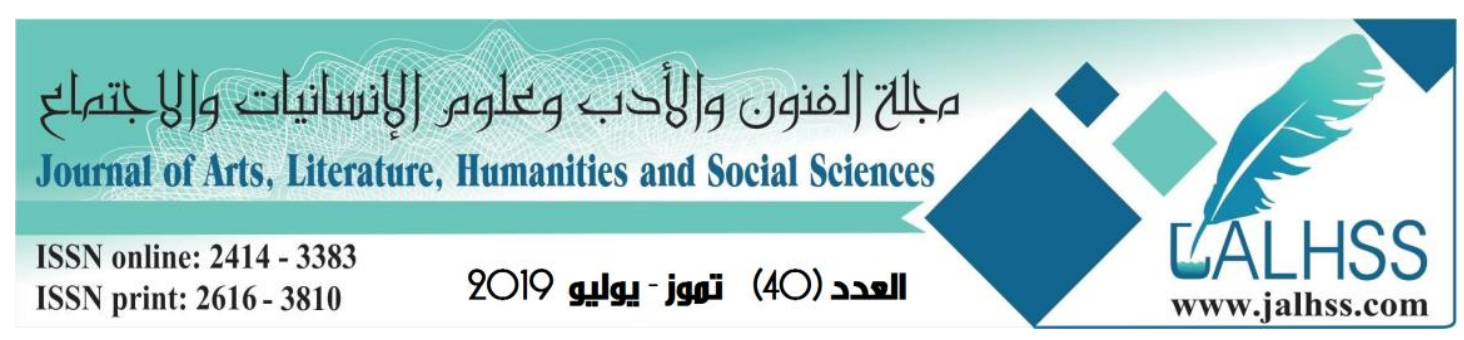

further investigation. To further understand the nuances of the feedback, the educators should thoroughly and systematically scrutinise their annotation practices and share their findings. Further analysis with future research, can examine with greater acumen factors including the teachers' grammatical conversance, training, experience and stances regarding feedback. Also, further analysis will help to indicate better the students' participation, motivation and attitudes toward feedback. It is apparent that further research concerning the teachers' awareness of the nature of feedback groups is required to enhance the application of strategies and the use of feedback.

\subsection{Recommendations}

Teachers had to train the Iraqi students to practice peer feedback as the concept was new to them. Other techniques can aid the fostering of learner autonomy alongside peer correction. Examples of these techniques include assigning pair work, group work or project homework; the class can negotiate the topic or material with the teacher; furthermore, enhance this activity with classroom debates and discussions on the chosen topics. These collaborative techniques work to reinforce the concepts of learner autonomy. The students eventually acquire the responsibility for their learning, rather than passively receive authoritative input.

The teacher has to prevent peer belittlement and ensure that the students remain confident in a 'safe' learning classroom environment; the teacher also must ensure that peer feedback is constructive, valuable and accurate.

The sole use of the Peer feedback tool is not a recommendation; other methods to provide feedback are still relevant since it is a false assumption to think that students consistently provide accurate feedback.

Above all, the orientation of students towards the 'new' role of a learner as an active participant, not a receiver enhances their progression. This proactive orientation occurs when teachers have confidence in this concept. Both teachers and learners must believe in the idea that active students' contribution, including negotiation in terms of creating 'meaning', facilitates useful learning development.

\section{References}

1. Al-Hamash, K. and Younis, H. (1983) Principles and Techniques of Teaching English as a Second Language. Baghdad.

2. Al-Hassan,H. and Razzak, F.(1981) College Composition. Baghdad

3. Al-Mutib, Saleh. (1989). Punctuation and reading comprehension among seventh and eighth grade students in a university lab school: an assessment. Ph.D. Florida State University Order No. AAD9004988 Source DAI P3195 Vol 50/10-A.

4. Ashwell, t., 2000) Patterns of Teacher Response to Student Writing in A Multiple-draft Composition Classroom: is content feedback followed by form 


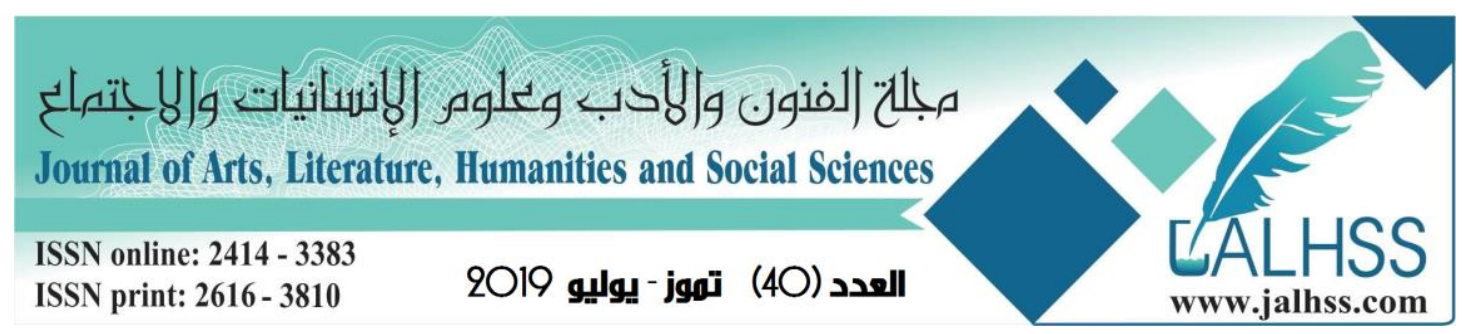

feedback the best method, in: journal of second language writing, 9(3), pp. 227-257.

5. Brown, H. Douglas. 2004. Language Assessment: Principles and Classroom Practices. White Plains. New York: Pearson Education, Inc.

6. Brown, H.D. (2007). Principles of language learning and teaching (5th ed.). White Plains, NY: Pearson Education.

7. Diab, n. M., 2010, „effects of peer-versus self-editing on students' revision of language errors in revised drafts", in: system, 38, pp. 85-95.

8. Fowler W.S. (1989). Progressive Writing Skills. Surry: Thomas Nelson and Sons Ltd.

9. Greenbaum, S. and Nelson, G. (2009). An Introduction to English Grammar. Longman.

10. Harmer, J. (2007) How to Teach English. Longman.

11. Harmer, Jeremy. 2001. The Practice of English Language Teaching. $\left(3^{\text {rd }}\right.$ Edition). New York: Pearson Education Limited.

12. Kasule, D. and Lunga, B. (2010) How Effective are Students self-Editing Endeavour? Evidence from L2 writing task: University of Boston. International journal for cross disciplinary subject in education (IJCDSE), Volume 1.

13. Liming Deng. (2003). Hints of Systematic Research of Process Teaching to College English Teaching. Foreign Language Teaching

14. Livingston, Kathy. 2001. "Guide to Writing a Basic Essay". (http://members.tripod.com/ lklivingston/ essay/topic.html. accessed on 20 September, 2014 at 10 a.m.

15. Makino, T. Y. (1993). Learner self-correction in EFL written compositions. ELT Journal 47.4, 337-341.

16. Marthen, L. N. (2010) Writing Processes, Tools and Techniques. New York: Nova Science Published, Inc.

17. Murray, D. (1980). Writing as Process: How Writing Finds its Own Meaning. In T.R. Donovan and B.W.MecClelland(eds), English Approach in Teaching Writing Negotiations: revision activities in esl writing instruction", in: tesol quarterly, 28, pp. 745-769.

18. Oshima, A and Ann H.(1999) Writing Academic English.(3rd. ed). White plains, New York; Addison whisley Longman.

19. Oshima, Alice and Hogue, Ann. 1991. Writing Academic English: A Writing and Sentence Structure Handbook. 2nd Ed. London: Addison-Wesley Publishing Company, Inc.

20. Paulston, C. B., \& Bruder, M. N. (1976). Teaching English as a second language: techniques and procedures. Cambridge, Massachusetts: Winthrop Publishers. 


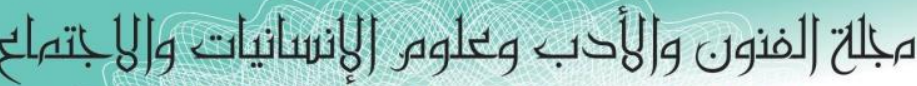

Journal of Arts, Literature, Humanities and Social Sciences

ISSN online: 2414 - 3383

ISSN print: 2616 - 3810

\section{العدد (4O) تموز - يوليو 2019}

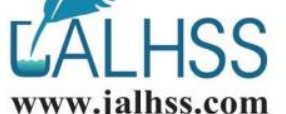

21. Richards, Jack, C. and Willy Renandya. (2002).Methodology in Language Teaching: An Anthology of Current Practice. London: Cambridge University Press.

22. Rief, L. (1990). Finding the value in evaluation: Self-evaluation in a middle school classroom. Educational Leadership 47.6, 24-29.

23. Sultana, A. (2009). Peer correction in ESL classroom. BRAC University Journal 6.1, 11-19. [30].

24. Truscott, j. (2004) Evidence and Conjecture on The Effects of Correction: AResponse to Chandler", in: journal of second language writing, 13, pp. 337343.

25. Tsui, b. M.; ng, m. (2000) Do Secondary 12 Writers Benefit From Peer Comments?", in: journal of second language writing, 9 (2), pp. 147-170.

26. Zemach, Dorothy E. and Lisa A Rumisek. (2003). Academic Writing from Paragraph to Essay. Spain: Macmillan. 